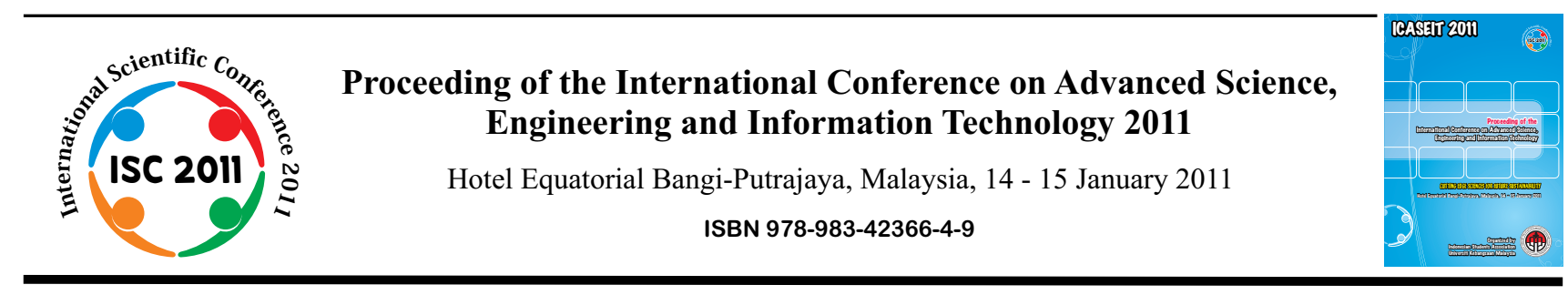

\title{
Subsidence and Deforestation: Implications for Flooding in Delta's Southeast and East Asia
}

\author{
Nurhamidah, Nick van de Giesen, Olivier Hoes \\ Department of Water Management, Civil Engineering and Geosciences \\ Delft University of Technology, the Netherlands \\ Stevinweg 1, PO Box 504, 2600 GA Delft, The Netherlands \\ Tel.: +31152782168 \\ Email: nurhamidah@tudelft.nl, $\underline{\text { n.c.vandegiesen@tudelft.nl, O.A.C.Hoes@tudelft.nl }}$
}

\begin{abstract}
Delta is a low-lying area which can be found at the mouth of a river. Nowadays, concentration of flooding occurs in many deltaic areas due to combination of several factors. Meanwhile, a big number of people live on flood plain of main rivers and river deltas which will be threatened by flooding. Land subsidence and deforestation are two phenomena which had been occurring very high until recently in SEE Asia region. Increasing of population strongly influences the natural hydrological processes. Due to pressure for land, substantial areas of peat swamps in SEE Asia have been presently are being reclaimed for agriculture or for other land use. In natural conditions swamp areas functioned as a retention area by adsorbing flood water, thereby preventing or mitigation flooding in downstream areas. But unfortunately, large areas of the original forests in large peat swamp forests have disappeared due to human activities such as illegal logging and fires. In other side increasing population, industries, agricultures and plantations will increase water demand. Activities of ground water extraction will be increasing as well. It can cause land subsidence and furthermore tide can easily propagate into deltaic areas moreover compounded by lowering of land surface due to land subsidence. Since flooding is an issue has been identified then these two phenomena need to be identified as well.
\end{abstract}

Keywords— delta, flood, land subsidence, deforestation, fires.

\section{INTRODUCTION}

Delta is a low-lying area which can be found at the river mouth. A big area of Southeast and East Asia (SEE Asia) region are located below $100 \mathrm{~m}$ elevation zones (figure 1a), whereas in the same places, flooding occurs frequently at many large coastal cities in SEE Asia region (figure 1b). According to [26] during the next century, many of the world's low-lying coastal zones and river deltas could be inundated. Several of the world's most heavily populated coastal cities are particularly vulnerable to inundation due to human interactions with deltaic processes. This is especially likely to be the case in low lying coastal sites, as a prelude to their eventual permanent inundation and abandonment. Meanwhile, during the last 2000 years, amount of rivers together deposited more than $40 \mathrm{~km}^{2}$ of new land annually as delta plains along the SEE Asian coasts. At present new land formation has reached a standstill; some deltas are even shrinking [31].

Several processes such as high tides due to astronomical tidal activity, wave action caused by winds, high sea levels combining with high river flows, and accelerated sea level rise due to global warming also play important roles in coastal flooding. It will be getting worse in places where land subsidence occurs. The seas east of China are one of the world's major shallow water areas, whereas tides ranges can exceed $4 \mathrm{~m}$ at many coastal ports, are of major importance in coastal processes, in influencing man's activities near the coast and in the transport of sediments. It has been reported that the some coastal areas are subsided relative to mean sea level.

Although floods are not usually deadly they can cause lots of crops, public facilities and house's damage. Generally in deltaic areas, flooding can be caused by a combination of several factors but virtually each of the factors may not be very dangerous when taken separately but their combination can leads to flooding. When heavy rainfall occurs during high tidal flow, then a critical flooding condition will occur instantaneous. Since flooding is an issue has been identified then type and direct/indirect causes of flooding need to be identified as well. This study describes (direct/indirect) causes for flooding in delta's SEE Asia region; land subsidence and deforestation which have implications to flooding. 


\section{FLOOD HAZARDS MAPPING IN SEE ASIA REGION}

Floods affected a large number of people throughout Southeast Asia. According to World Commission on Dams [8], between 1990 and 2006 there were approximately 208 flood events, which affected approximately 58 million people and killed 9,912 people. Flooding continues to be a challenge for most cities in the region. Some of the flooding challenges for selected cities in the region are listed in Vientiane, Phnom Penh, Manila, Jakarta and Kuala Lumpur [6], [8], [23] and annually occurrences in Vientiane. There were flash floods in tributaries of the Mekong River in Laos, Thailand and the Central Highlands of Viet Nam that caused significant damage. Therefore, floods occurred such as flood inundation in low lying areas and flash floods in mountainous areas. As for the frequently flood problem from the past until now flood destroy many lives and properties

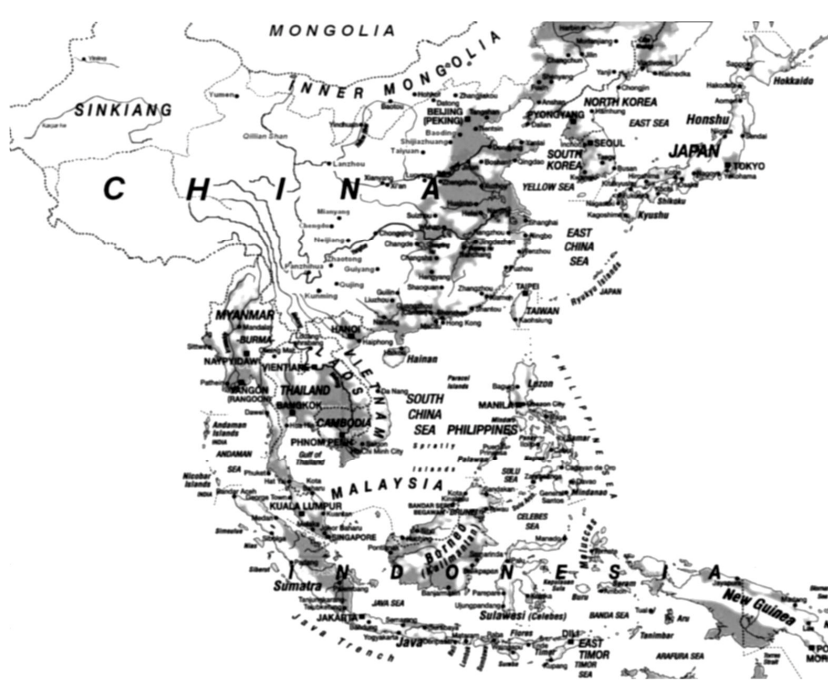

Figure 1a. Lowland areas less than $100 \mathrm{~m}$ elevation.

TABLE 1 OVERVIEW OF FLOODS OCCURRENCE DURING THE LAST DECADE IN SEE ASIA

\begin{tabular}{|l|c|l|r|r|r|}
\hline Country & $\begin{array}{l}\text { Number of } \\
\text { floods }\end{array}$ & Type & Killed & Total affected & $\begin{array}{l}\text { Est. Damage } \\
\text { (US\$ Million) }\end{array}$ \\
\hline Cambodia & 8 & G & 455 & 6644235 & 176,1 \\
\hline China & 98 & G,F,SC & 5774 & 528277840 & 37892,821 \\
\hline Indonesia & 61 & G,F,SC & 2810 & 3409309 & 1615,139 \\
\hline Japan & 10 & G,F,SC & 113 & 460594 & 9397 \\
\hline Lao P & 5 & G & 33 & 1257190 & 1 \\
\hline Malaysia & 23 & G,F,SC & 112 & 413564 & 1001 \\
\hline Mongolia & 3 & G,F,SC & 41 & 15650 & 0,364 \\
\hline Myanmar & 7 & G & 102 & 230414 & 0 \\
\hline North Korea & 11 & G,F,SC & 198 & 341940 & 477,595 \\
\hline Philippines & 44 & G,F,SC & 600 & 5619447 & 133,499 \\
\hline South Korea & 9 & G,F,SC & 1229 & 1724372 & 329,4 \\
\hline Taiwan & 2 & G,F & 19 & 3000 & 178,13 \\
\hline Thailand & 31 & G,F & 959 & 13019075 & 656,561 \\
\hline Timor-Leste & 5 & G & 5 & 4505 & 0 \\
\hline Viet Nam & 37 & G,F,SC & 2000 & 10996304 & 1886,8 \\
\hline
\end{tabular}

Most floods, like most other natural disasters, much occur in SEE Asia region. In this region the number of people killed and affected are vastly higher than in more

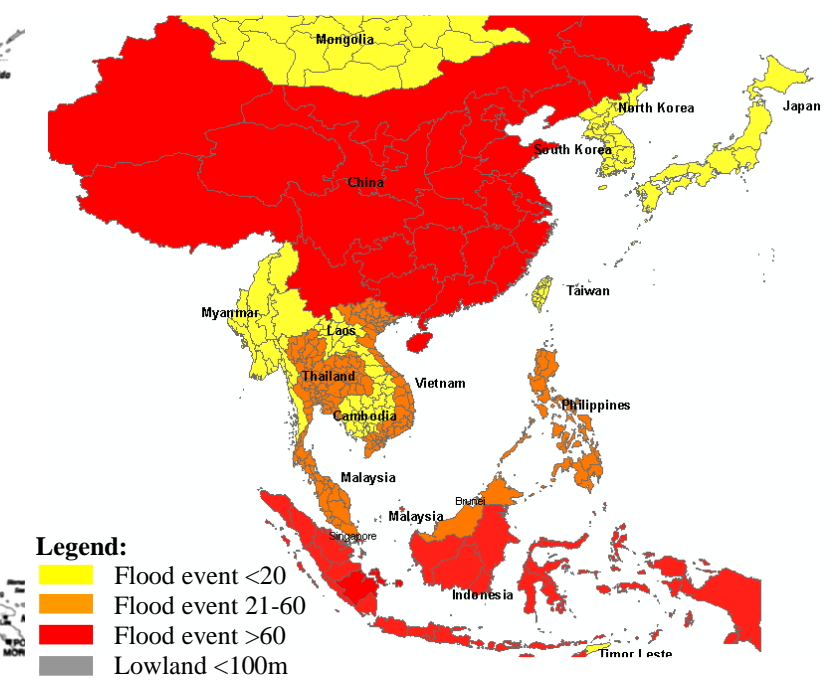

Figure 1b. Flood hazard mapping in SEE Asia

and tend to become worst in the future. Because Thailand is located in monsoon area, the problems have been prevented and resolved by develops the hydraulic structure, increases the efficiency of drainage the water from flood plain and such. By the past 30 years, Thailand had faced the flood problem up to 10 times in almost every provinces, and there were 6 times more violence in 1975, 1983, 1995, 2002, 2005, and 2006, which the flood occurrence in 2008 [35].

During last decade (2000-2009), 354 frequencies of flood occurred in amount of countries in SEE Asia with total estimation of damage came out at US\$ 657 million. China is most frequently occurring of flood due to general flood; flash flood and coastal flood. Based on The International Disaster database, figure 1 and table 1 show an overview of floods which occurred at last decade in countries at SEE Asia region.

Flood event $>60$ Lowland $<100 \mathrm{~m}$

highly developed countries. People from the lower socioeconomic strata are worse affected and, sadly, they are the ones who also have the least access to health services. Flood 
damage may be the consequences of man's activities in areas at risk from flooding which means flood damages can be categorized into tangible and intangible, direct and indirect, and primary, secondary and tertiary ones [25], [27]. Primary impacts occurs as damage as a results of the flood itself. Secondary impacts occur only because the flood has caused them. Primary impacts are the immediate effects. These impacts lead to further effects, those so-called secondary losses. Tertiary impacts are long term impacts that are set off as a result of flood event. These include for example loss of habitat, permanent changes in the river course or crop failure caused by a flood. Land subsidence and deforestation are categorized into intangible damages, indirect causes and tertiary impacts of flood.

\section{SUBSIDENCE AND DEFORESTATION}

\section{A. Land Subsidence}

Relationship between flood and land subsidence was indicated from 48 case studies where the maximum increase in flooding depth was found to be less than one-third of the related ground subsidence [29]. This also can occur in many parts around the world. The phenomenon of subsidence can be found from results of the heavy withdrawal of groundwater, geothermal fluids, oil, and gas, the hydrocompaction of sediments; oxidation and shrinkage of organic deposits and other phenomena. Land subsidence due to groundwater abstractions has much common. As usual, oil and gas are withdrawn from much greater depth than groundwater, thus physical and geological conditions are often rather different. Damages which are resulted from land subsidence results damage normally are not evident in a short time period. The problem created by land subsidence include decline of land elevation, creating inundation of floodwaters during typhoons, spring tides, rainstorms and during period of high tide.

According to Yamamoto [19] the number of subsidence areas in Japan has reached 40 and is still increasing. Most of the subsidence is due to groundwater withdrawal from thickly populated topographically low areas bordering the ocean. In Sanghai, land subsidence is an enormous potential hazard which is a coastal city with low elevation [18]. Subsidence in costal areas can be directly correlated to an increase in tidal flooding. While the land surface is lowered, the sea level and storm surge levels remain constant. Thus each one centimetre of subsidence results in an increased depth of flooding of one centimetre as well. Generally, increases in gradient resulted in decreases in the depth of flooding and, conversely, decrease in gradient causes increases in the depth of flooding [29].

Increasing water withdrawals in urban, industrial and agricultural use have profoundly altered the hydrology of many major rivers worldwide [24]. Every part of the world that withdraws groundwater at rates greatly exceeding those of recharge experiences serious subsidence. The problem is especially serious in East Asian coastal zones. There, many metropolitan areas have experienced worsening floods attributed to several centimetres per year of subsidence due to excessive groundwater withdrawal (see table 2 with references therein)

TABLE 2 LAND SUBSIDENCE IN SOME SE/E ASIA COUNTRIES

\begin{tabular}{|c|c|c|c|c|}
\hline \multirow[t]{2}{*}{ Location } & \multicolumn{4}{|c|}{ Subsidence (cm) } \\
\hline & Land use & Period & Cumulative & Rate (cm/year) \\
\hline \multicolumn{5}{|l|}{ Japan [19], [34],[41] } \\
\hline Tokyo & Metropolis & $1900-76$ & 440 & 2.7 \\
\hline Osaka & Metropolis & $1934-68$ & 290 & 8.2 \\
\hline Nobi & & $1950-1973$ & $>20$ & 2.0 \\
\hline Aomori & & $1958-78$ & 45 & 2.3 \\
\hline Sendai & & 1966-78 & 57 & 2.0 \\
\hline Haranomachi & & $1965-78$ & 200 & 1.7 \\
\hline Shirioshi plan, Kyushu & Agriculture & $1960-98$ & 123 & 3.2 \\
\hline Incl. Nanao, Niigita, Hyogo and Saga & & & & $1.7-8.2$ \\
\hline \multicolumn{5}{|c|}{ China [10], [11], [12], [17], [33], [34], [39], [40] } \\
\hline \multirow[t]{4}{*}{ Shanghai } & Metropolis & $1921-65$ & 263 & 6.0 \\
\hline & & $2002-03$ & & 1.3 \\
\hline & & 2003 & & $0.8-5.6, \max 16$ \\
\hline & & $1990-2000$ & & 16 \\
\hline Hangu city & Metropolis & $1980-97$ & $>100$ & $5-9$ \\
\hline \multirow[t]{2}{*}{ Tianjin } & Metropolis & $1959-03$ & 306 & \\
\hline & & 2003 & & $0.8-5.6, \max 16$ \\
\hline Suzhou & Metropolis & 1960-03 & 110 & $4-5$ \\
\hline Changzou & Metropolis & 1960-03 & 90 & $4-5$ \\
\hline Jiaoling & Metropolis & 1960-89 & 60 & 5 \\
\hline $\begin{array}{l}\text { Incl. Wuxi, Huang-huai-hai plain, } \\
\text { Hang-Jia-Hu and Xi'an }\end{array}$ & & & & $1.0-16.0$ \\
\hline \multicolumn{5}{|l|}{ Indonesia [1], [2], [3], [4], [5], [14] } \\
\hline \multirow[t]{5}{*}{ Jakarta } & Metropolis & 1980-99 & 260 & \\
\hline & & $1982-97$ & $20-200$ & $20-25$ \\
\hline & & $1991-97$ & & 26.7 \\
\hline & & $1997-99$ & & 10 \\
\hline & & 1997-05 & & $1-10$ \\
\hline Semarang & Metropolis & $1996-2001$ & & 17 \\
\hline Bandung & Metropolis & $2000-2008$ & & $7.6-23$ \\
\hline Kalimantan & Tropical peat land forest & $1972-86$ & 30 & $2.4-5.3$ \\
\hline \multicolumn{5}{|l|}{ Taiwan [9], [21], [22], [34], [36] } \\
\hline Taipei & Metropolis & since $1970 \mathrm{~s}$ & -250 & 10 \\
\hline
\end{tabular}




\begin{tabular}{|c|c|c|c|c|}
\hline $\begin{array}{l}\text { Chosui delta, including "Yun lin } \\
\text { basin" }\end{array}$ & & $\begin{array}{l}1969-01 \\
1985-94 \\
1998-01\end{array}$ & $10-130$ & $\begin{array}{l}5.6 \\
20 \\
3-15\end{array}$ \\
\hline Poi-Kang_Tsang-Wan deltas & Aqua and agriculture & $\begin{array}{l}1955-95 \\
1991-92 \\
\end{array}$ & & $\begin{array}{l}5-10 \\
6-20 \\
\end{array}$ \\
\hline Pingkung plan & & $1996-99$ & & $3-6$ \\
\hline \multicolumn{5}{|l|}{ Vietnam [13], [15] } \\
\hline \multirow[t]{2}{*}{ Hanoi } & Metropolis & $1988-93$ & $10-15$ & $2-6$ \\
\hline & & 1998 & & 2 \\
\hline Ho Chi Minh city & & & & $1.2-6.0$ \\
\hline \multicolumn{5}{|l|}{ Philippines [30] } \\
\hline Manila & Metropolis & $1991-2003$ & $>100$ & $5-9$ \\
\hline Pampanga delta & Aqua and agriculture & & $>100$ & $3-9$ \\
\hline \multicolumn{5}{|l|}{ Thailand [34] } \\
\hline \multirow[t]{4}{*}{ Bangkok } & Metropolis & $1978-81$ & & $5-10$ \\
\hline & & $1989-90$ & & $1-3$ \\
\hline & & $1980-90$ & & $5-10$ \\
\hline & & 1992-02 & & 3-4 avg. $>8$ max \\
\hline \multicolumn{5}{|l|}{ Malaysia [16], [28], [38] } \\
\hline Kualalumpur & Metropolis, & $1963-1993$ & & 24 \\
\hline $\begin{array}{l}\text { Kelantan, Sabah, Peninsular and East } \\
\text { Malaysia }\end{array}$ & Tropical peat land forest & $\begin{array}{l}1960-74 \\
1974-88 \\
1988-97\end{array}$ & 300 & $\begin{array}{l}2.0-12 \\
4.6 \\
2.0 \\
\end{array}$ \\
\hline
\end{tabular}

Meanwhile worldwide, peat swamp forests have been estimated to cover around $350,000 \mathrm{~km}$ square. Due to pressure for land, substantial areas of peat swamps in SEE Asia have been presently are being reclaimed for agriculture or for other land use for instance: Indonesia and Malaysia. As tropical peat in tidal swamplands areas, Sumatera, Kalimantan, Peninsular Malaysia and East Malaysia are identified with land subsidence on the peat layers. Land subsidence rates vary from 2.4 until $5.3 \mathrm{~cm}$ per year in Borneo since the large-scale reclamation of tropical peat in tidal swamplands areas for agriculture through the installation of irrigation-drainage system has been carried at 1970. The cumulative subsidence was $30 \mathrm{~cm}$ during period 1972-1986 [14], [38]. Whereas the average subsidence rate for area in Peninsular Malaysia was found to be 2 until 12 $\mathrm{cm}$ per year, as soon as peat swamps are drained, the irreversible process of subsidence starts. The cumulative subsidence in Malaysia found $300 \mathrm{~cm}$ since 1960 until 1997. Those subsidences were due to consolidation, whereas in exposed peat layer subsidence resulted from shrinkage and oxidation process. Records on peat subsidence in South East Asia (lowland oligotrophic coastal peats) indicate $50 \mathrm{~cm}$ to $1 \mathrm{~m}$ in the initial years after reclamation with a subsequent decrease to less than $6 \mathrm{~cm}$ per year [7]. According to Andriesse [7], conditions in South East Asia where deep almost pure peat is being covered by mineral deposits because of deforestation of the catchments. Deforestation causes erosion of mineral topsoil and increases the silt load of the river. It also increases the risk of flooding in downstream peat areas.

Subsidence will be increased rapidly from a combination of causes: consolidation and oxidation of peat, induced by lowering of surface water levels, and intensification of agriculture. It is generally understood that the rate of subsidence varies strongly and depends on an a number of factor, such as the type of peat, rate of the composition, density and thickness of peat layer, drainage depth, climate, land use and history of development. Therefore the total subsidence indicates the lowering of soil surface. Total subsidence due to drainage of peat soil can be subsided into three components; consolidation, oxidation and shrinkage [32]. Land subsidence due to oxidation of organic soils (histosols) in drained agricultural catchments can enhance local flood hazard. Large agricultural areas in Malaysia and Indonesia are characterized by soils with high organic content (peat) were reclaimed for oil palm plantation until now. In other hand, land reclamation for agriculture areas by forest fires on peat layers vastly accelerate the lowering of land surface.

\section{B. Deforestation}

Increasing of population growth will be therefore pressure on the available land resources. This situation strongly influences the land-use in a catchment area. The change of land use without considering the impacts on the hydrological system and the environment cause disturbances to natural hydrological processes. The land-use changes adversely affect areas that naturally absorb (flood) waters such as; swamps, forests, etc. Loss of natural absorbs (flood) water increases storm water runoff and decreases groundwater recharge; this leads to flash floods in the catchment.

Actually, in natural conditions swamp areas function as a retention area by adsorbing flood water, thereby preventing or mitigation flooding in downstream areas. It was note more than 60 per cent of the world's tropical peat lands are to be found in SEE Asia; on the islands of Borneo (belonging to Indonesia, Malaysia and Brunei Darussalam) and Sumatra (Indonesia), also significant areas in other parts of Indonesia, Malaysia, Vietnam, Thailand and the Philippines [37]. But unfortunately, large areas of the original forests in large peat swamp forests have disappeared due to human activities such as illegal logging. Logging by groups from the surrounding villages had been very high until recently. It was reported that some of this logging has been conducted by local villagers, but also larger operations that involve logging crews from outside this area. Many peat swamp forest areas have been subject to uncontrolled (illegal) development activities, including illegal logging and urban developments. Large scale plantation companies, however, are now finding the swampy areas increasingly attractive for various reasons. In Indonesia itself, since the 1990s official 
development of peat lands has focused mainly on oil palm, as plantation replacement. In addition, large scale clearing for agriculture and transmigration also continued as government policy for distribution of population. All these activities could be adversely impacting the generation of floods in the catchment, leading to an increase of downstream flooding. The situation will be getting worst when reclamation of swamp forest by fire of forest. Figure 2b shows the fires incident during 2008 and 2009 in some areas along SEE Asia and table 3 figures the number of fires which occur during 2005-2009 in SEE Asia's countries. In China, forest fires was reported by International disaster database occurring at 1987, with 191 numbers of people killed and more less 60,000 people affected. At 1997, Indonesia was reported with El Nino resulted in a greatly extended dry season, in which peat land fires in Sumatra and Kalimantan were intensive sources of Smoke and particulate matter reaching the atmosphere. At that time, peat land fires burned both vegetation and substrate and role of peat land in the release of carbon to the atmosphere during the 1997 fires. It was reported also by International disaster database that 240 people are killed, 3 million affected and cause 8 billion US dollar. Indeed, swamp forest fires of Kalimantan and Sumatera have known since 1986 and 1988. Fires on peat continuously can disappear several layers of land surface and these phenomena can cause additional land subsidence as well following by increasing the depth of flooding. However, fires of swamp forest which covered by peat layer can immediately clear the layer of peat.

Due to the process oxidation, shrinkage and consolidation on peat layer compounded by the human activities such as deforestation by fires and excessive ground water withdrawal, so the land surfaces condition especially on swamp peat land can be illustrated as following figure 3 . Peat layer can be loss quickly by fires and loss slowly by process of oxidation, shrinkage and decomposition without rewetting all peat layers above drainage base on river level.

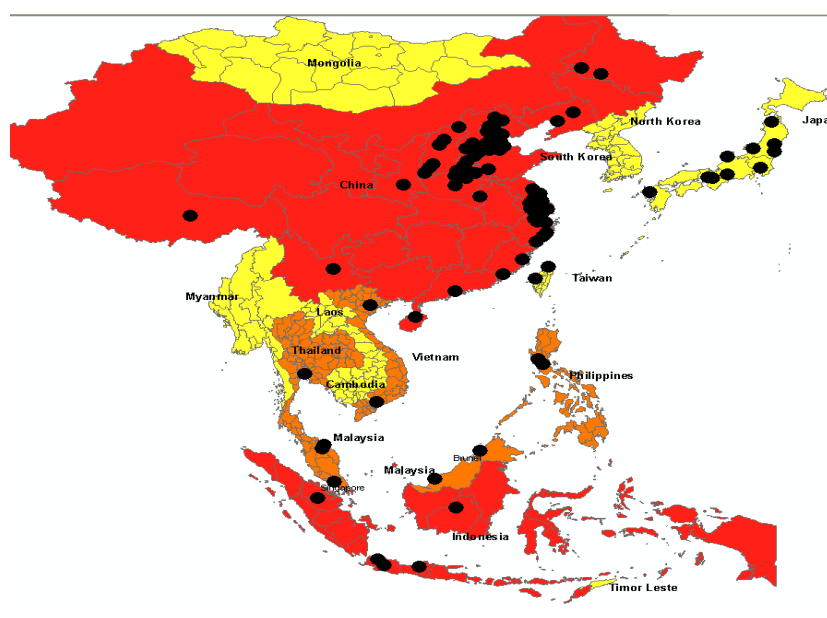

Figure 2a. Land subsidence mapping along SEE Asia.

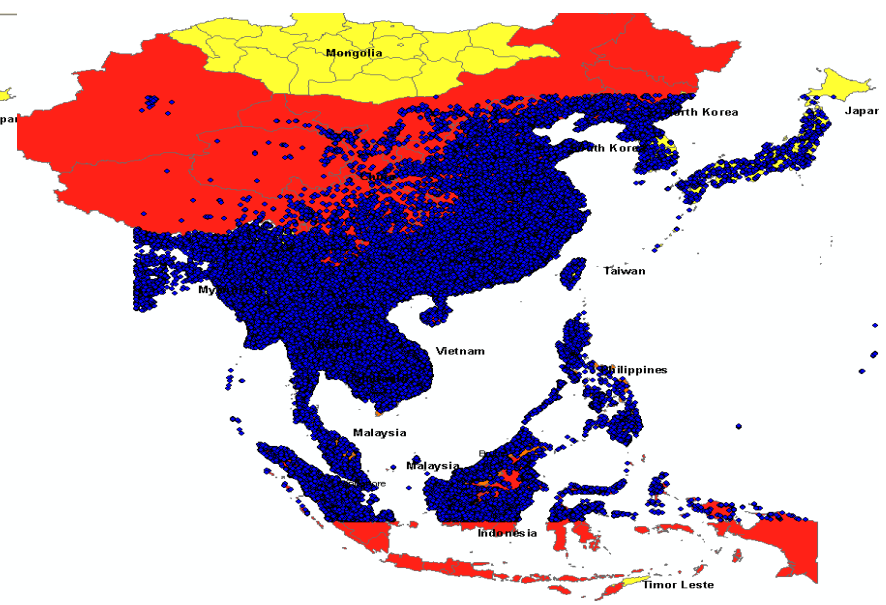

Figure 2b. Fire incident mapping (hotspot) along SEE Asia

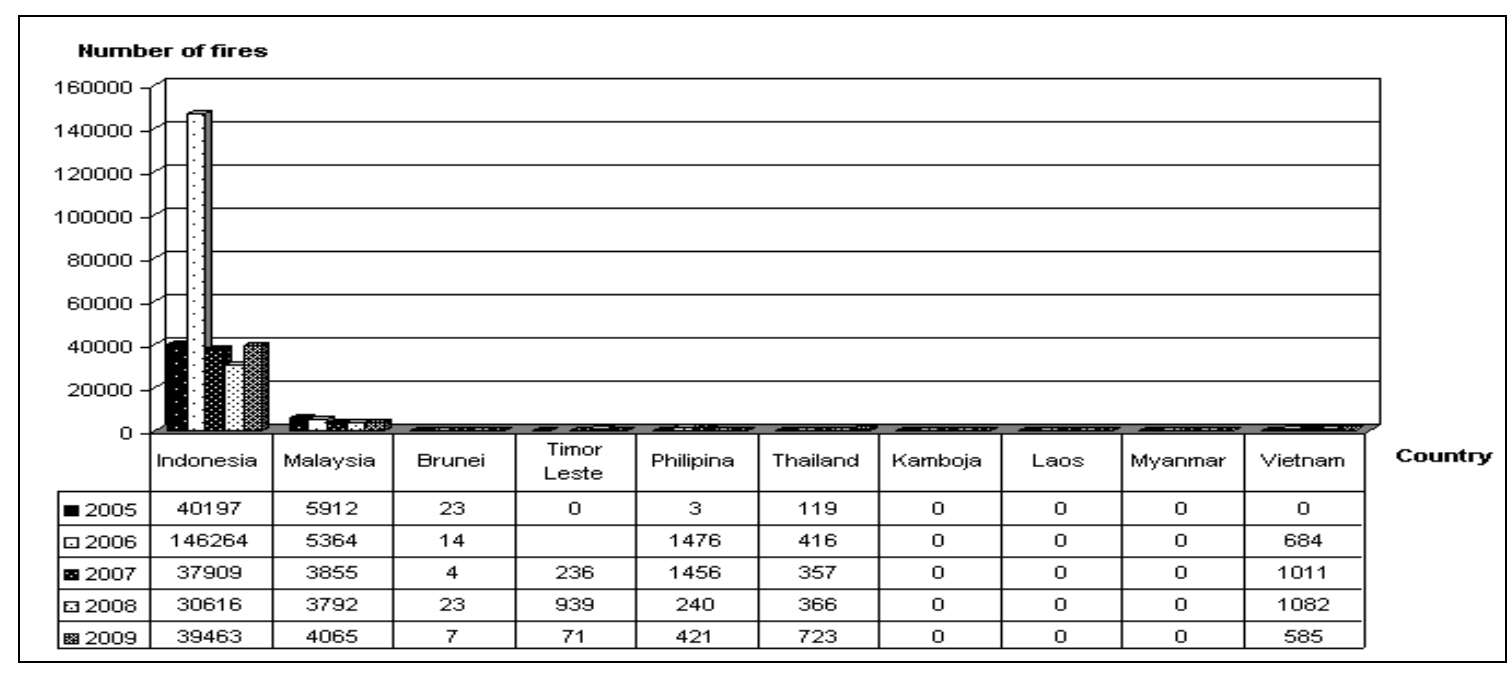

Table 3 Fires incident during 2005-2009 in SEE Asia's countries 


\section{CONCLUSSION}

Flooding in deltas SEE Asia region have more significant impacts when combination of several issues such as; land subsidence, lowland reclamation and sea level rise threaten in same time. The hazard will be exacerbated when development of deltas areas and reclamation are doing without considering the impacts on the hydrological system and the environment. As a consequence, life of habitats in deltas will be threatened by flooding which can occur anytime. Other consequence, deforestation tends to reduce evapotranspiration, swamp areas can not be functioned as natural storage since the forest have been reclaimed to the uncontrolled process of agricultures and plantation.

\section{ACKNOWLEDGEMENT}

We would like to thank The Fire Information for Resource Management System (FIRMS) and The International Disaster Database (EM-DAT) who provides data and Andalas University for funding this research.

\section{REFFERENCES}

[1] Abidin, H. Z., H. Andreas, et al. (2008). Land subsidence characteristics of Jakarta between 1997 and 2005, as estimated using GPS surveys. GPS Solut 12:23-32.

[2] Abidin, H. Z., H. Andreas, et al. (2008). Land subsidence characteristics of the Jakarta basin (Indonesia) as estimated from Leveling, GPS and InSAR and its relation with groundwater extraction. 36th IAH Congress, Integrating Groundwater Science and Human Well-being, Toyama, Japan.

[3] Abidin, H. Z., H. Andreas, et al. (2009). Land subsidence and urban development in Jakarta (Indonesia). 7th FIG Regional Conference Spatial Data Serving People: Land Governance and the Environment - Building the Capacity, Hanoi, Vietnam.

[4] Abidin, H. Z., H. Andreas, et al. ( 2009). Land subsidence and groundwater extraction in Bandung basin, Indonesia. Trends and Sustainability of Groundwater in Highly Stressed Aquifers (Proc. of Symposium JS.2 at the Joint IAHS \& IAH Convention), Hyderabad, India, IAHS

[5] Abidin, H. Z., R. Djaja, et al. (2001). Land subsidence of Jakarta (Indonesia) and its Geodetic Monitoring System. Natural Hazards 23 365-387(Kluwer Academic ).

[6] ADB (2004)._Water in Asian cities, Asian Development Bank

[7] Andriesse, J. P., Ed. (1988). Nature and management of tropical peat soils.

[8] Asmal, K. (2000). Dams and development. A new framework for decision-making. The world commission on dams.

[9] Chai, J. C., S. L. Shen, et al. (2004). Land subsidence due to groundwater drawdown in Shanghai. Geotechnique 54(2): 143-147.

[10] Cui, X., X. Niu, et al. (2002). Prevention and control of land subsidence in Tianjin (in Chinese) In Wei ZX, Li QF (eds) Proceeding of the national symposium on land subsidence Sanghai institute of Gelogy survey, Shanghai.

[11] Damoah-Afari, P., X.-1. Ding, et al. (2007). Six years of land subsidence in Shanghai revealed by JERS-1 SAR data. 1-4244-12: 2093-2097.

[12] Damoah-Afari, P. and X. L. Ding (2005). Measuring ground subsidence in Shanghai using permanent scatterer insar technique. The 26th Asian Conference on Remote Sensing (ACRS2005), Hanoi, Vietnam.

[13] Dinh, H. T. M., L. V. Trung, et al. ( 2008). Measuring land subsidence in Ho Chi Minh city by means of radar interferometry techniques. International Symposium on Geoinformatics for Spatial Infrastructure Development in Earth and Allied Sciences.

[14] Dradjad, M., S. Soekodarmodjo, et al. (2003 ). Subsidence of peat soils the tidal swamplands of Barambai, South Kalimantan. Jurnal Ilmu Tanah dan Lingkungan Vol 4 (1) 32-40.

[15] Giao, P. H. and E. Ovaskainen (2000). Preliminary assessment of Hanoi land subsidence with reference to groundwater development. Lowland technology International 2(2)
[16] Haryono (1995). Relation between groundwater withdrawal and land subsidence in Kelantan, Malaysia. Land Subsidence (Proceedings of the Fifth International Symposium on Land Subsidence), The Hague, the Netherlands.

[17] Hu, R. L., Z. Q. Yue, et al. (2004 ). Review on current status and challenging issues of land subsidence in China. Engineering Geology 76: 65- 77.

[18] Hua, Z., L. Tiezhu, et al. (1993). Economic benefit risk assessment of controlling land subsidence in Shanghai. Environmental Geology 21: 208-211.

[19] Joseph F. Poland, C. a. E. (1984). Guidebook to studies of land subsidence due to ground-water withdrawal, UNESCO.

[20] Lang, G. (2002). Deforestation, floods, and state reactions in China and Thailand. The Environmental State Under Pressure 10 195-220.

[21] Liu, C.-H., Y.-W. Pan, et al. (2004 ). Characterization of land subsidence in the Choshui River alluvial fan, Taiwan. Environmental Geology 45: 1154-1166

[22] Liu, Y. B., F. D. Smedt, et al. (2004). Assessing land use impacts on flood processes in complex terrain by using GIS and modeling approach. Environmental Modeling and Assessment 9(Kluwer Academic).

[23] Marcotullio, P. J. (2007 ). Urban water-related environmental transitions in Southeast Asia. Sustain Sci 2: 27-54.

[24] Molle, F., P. Wester, et al. (2010). River basin closure: Processes, implications and responses. Agricultural Water Management 97: 569-577.

[25] Moramarco, T., F. Melone, et al. (2005). Assessment of flooding in urbanized ungauged basins: a case study in the Upper Tiber area Italy. Hydrological Processes 19: 1909-1924.

[26] Nicholls, R. J., P. P. Wong, et al. (2008 ). Climate change and coastal vulnerability assessment: scenarios for integrated assessment. Sustainable Science 3: 89-102.

[27] Penning-Rowsell, E. C. and J. B. Chatterton (1977). The benefits of flood alleviation : a manual of assessment techniques, Farnborough, Eng. : Saxon House.

[28] Phua, M.-H., S. Tsuyuki, et al. (2007). Detection of burned peat swamp forest in a heterogeneous tropical landscape: A case study of the Klias Peninsula, Sabah, Malaysia. Landscape and Urban Planning 82 103-116.

[29] Potok, A. J. (1991). A Study of the relationship between subsidence and flooding. The fourth International Symposium on Land Subsidence, Houston, Texas, International Association Hydrological Sciences (IAHS)

[30] Rodolfo, K. S. and F. P. Siringan (2006 ). Global sea-level rise is recognised, but flooding from anthropogenic land subsidence is ignored around northern Manila Bay, Philippines. Disasters 30(1)(Blackwell Publishing, 9600 Garsington Road, Oxford, OX4 2DQ, UK and 350 Main Street, Malden, MA 02148, USA).

[31] Saito, Y., N. Chaimanee, et al. (2007). Shrinking Megadeltas in Asia: Sea-level Rise and Sediment Reduction Impacts from Case Study of the Chao Phraya Delta.

[32] Schothorst, C. J. (1977). Subsidence of low moor peat soils in the western Netherlands. Geoderma 17(Elsevier Scientific Publishing Company, Amsterdam-Printed in The Netherlands): 265-291.

[33] Shearer, T. R. (1998). A numerical model to calculate land subsidence, applied at Hangu in China. Engineering Geology 49

[34] Siringan, F. (2009). Ondoy Tragedy; Lessons to be learned.

[35] Sonnasinh, V. (2009)._Lao PDR's country flood report for 2008. 7th Annual Mekong Flood Forum.

[36] Tang, C.-P. and S.-Y. Tang (2006). Democratization and capacity building for environmental governance: managing land subsidence in Taiwan. Environment and Planning A 38: 1131 - 1147.

[37] UNDP (2006). Peat Swamp Forests, Ministry of Natural Resources and Environment, Malaysia.

[38] Wosten, J. H. M., A. B. Ismail, et al. (1997). Peat subsidence and its practical implications: A case study in Malaysia. Geoderma 78(1-2) $25-36$.

[39] Wu, J., X. Shi, et al. (2008). The development and control of the land subsidence in the Yangtze Delta, China. Environ Geol 55: 1725-1735.

[40] Xue, Y.-Q., Y. Zhang, et al. (2005 ). Land subsidence in China. Environ Geol 48 713-720.

[41] Yamamoto, S. (1995). Recent trend of land subsidence in Japan. Land Subsidence (Proceedings of the Fifth International Symposium on Land Subsidence), The Hague, The Netherlands, IAHS. 